\title{
Organic viticulture and soil quality: A long-term study in Southern France
}

\author{
Patrice Colla ${ }^{\mathrm{a}}$ Edith Le Cadre ${ }^{\mathrm{a}, *}$, Eric Blanchart ${ }^{\mathrm{b}}$, Philippe Hinsinger $^{\mathrm{c}}$, Cécile Villenave $^{\mathrm{b}}$ \\ a Montpellier SupAgro, UMR EcoESols, 34060 Montpellier, France \\ ${ }^{\mathrm{b}}$ IRD, UMR EcoESols, 34060 Montpellier, France \\ ' INRA, UMR EcoESSols, 34060 Montpellier, France
}

\section{A R T I C L E I N F O}

\section{Article history:}

Received 12 May 2011

Received in revised form 19 July 2011

Accepted 24 July 2011

\section{Keywords:}

Conventional viticulture

Bioindicators

Organic matter

Microbial biomass

Nematodes

Earthworms

\begin{abstract}
A B S T R A C T
The rate of conversion of conventional vineyards into organic farming is currently increasing. This results in modifications of agricultural practices such as the application of organic manure, the use of tillage or grass-cutting to control weeds and the application of natural pesticides with preventive action. One of the aims of organic farming is to preserve the environment. In this context, the objective of our work was to evaluate the long-term effects of organic viticulture on soil quality. The study was conducted in a commercial vineyard where plots which had been organically managed for 7 (Organic7), 11 (Organic11) and 17 years (Organic17) were compared to conventionally managed plots (Conventional). Soil physical and chemical parameters (bulk density, organic matter, available phosphorus, potassium and copper contents) and biological parameters (soil microbial biomass, density of nematode trophic groups and density and biomass of earthworm ecological categories) were measured. The organic farming led to an increase in soil organic matter, potassium content, soil microbial biomass, plant-feeding and fungalfeeding nematode densities. However, organic farming increased soil compaction, decreased endogeic earthworm density and did not modify the soil micro-food web evaluated by nematofauna analysis. Our study highlights the difficulty to show the benefits of organic farming on global soil quality in this particular pedoclimatic area and set of farming practices.
\end{abstract}

(C) 2011 Elsevier B.V. All rights reserved.

\section{Introduction}

For food and beverage safety issues, environmental considerations and economic interests are prompting more and more winegrowers to convert conventionally managed vineyards into organic farming. From 2001 to 2008, the area of organically managed French vineyards increased by $110 \%$ : 13,426 ha in 2001 (AgenceBIO, 2002) and 28,190 ha in 2008 (AgenceBIO, 2009). Conventional viticulture uses agrochemicals such as manufactured inorganic fertilizers and synthetic chemical pesticides. In contrast, these are banned in organic farming, while only organic fertilizers, crushed rocks and a few non synthetic pesticides are allowed (Briar et al., 2007). Instead of applying herbicides, weeds are managed by tillage or grass-cutting in organic farming. As a consequence, organic farming claims to reduce disturbance intensity of agricultural practices on the environment (Reganold et al., 1987), and especially on soil. Indeed, soil is a non-renewable resource and most vineyard soils are considered as highly degraded in terms of loss

\footnotetext{
* Corresponding author at: Montpellier SupAgro, UMR Eco\&Sols, bâtiment 12, 2 Place Pierre Viala, 34060 Montpellier Cedex 2, France. Tel.: +33 4996130 36; fax: +33499612119.

E-mail addresses: patrice.coll@ird.fr (P. Coll), lecadre@supagro.inra.fr (E. Le Cadre).
}

of organic carbon as a result increasing erosion and diminution of nutrient contents (Le Bissonnais et al., 2007; Martinez-Casasnovas and Ramos, 2009), accumulation of metals and organic pollutants (Chaignon et al., 2003; Komarek et al., 2010) or compaction due to tractor traffics (Coulouma et al., 2006). One of the main objectives of organic farming is to give more importance to soil biological functioning in order to improve its physical (affecting the circulation of water, aeration), chemical (affecting the availability of nutrients) and biological (affecting the biodiversity and fate of organic matter) properties (Van Bruggen and Semenov, 2000). Furthermore, in wine production, the soil is considered, together with climate, as a key component of Terroir (Van Leeuwen et al., 2004) which can influence the wine quality (Van Leeuwen and Seguin, 2006).

As defined by Doran and Parkin (1994) "the soil quality is the ability of a soil to function within ecosystem boundaries to sustain biological productivity, maintain environmental quality, and promote plant and animal health". Soil quality is generally evaluated by the interpretation of physical, chemical or biological indicators. Among physical and chemical indicators, those most used by winegrowers are soil bulk density, $\mathrm{pH}$, availability of major nutrients $(\mathrm{N}$, $\mathrm{P}, \mathrm{K}, \mathrm{Ca}, \mathrm{Mg}$ ), organic matter content which is known to increase soil water holding capacity (Teixeira et al., 2011), to promote soil aggregation (Le Bissonnais et al., 2007; Morlat and Chaussod, 2008) and to constitute a pool of available nutrients (Haynes, 1999). Biological indicators or bioindicators are considered to give an evaluation of 
soil functioning because soil organisms have intimate relationships with their surroundings (Franzle, 2006), and then can give information about soil degration or improvement (Bispo et al., 2011). The most widely studied are microorganisms and soil fauna (Huber et al., 2008; Bispo et al., 2011). Microorganisms are involved in different key processes in the ecosystems, such as the decomposition of organic matter, humus formation, soil aggregation, retention and cycling of nutrients, and various symbiotic and parasitic relationships with plants (Paul and Clark, 1996). Other useful bioindicators are nematodes and earthworms. To evaluate the soil food web, the soil nematodes are pertinent bioindicators because they present an important diversity of trophic groups such as plant-feeders, bacterial-feeders, fungal-feeders, omnivores and predators (Yeates et al., 1993; Villenave et al., 2004). Indeed, they are implicated in soil organic matter mineralization processes (Neher, 2001). In addition, they are ubiquitous and thus present in all pedo-climatic situations including habitats that vary from pristine to extremely degraded (Bongers and Ferris, 1999). Other representatives of soil fauna are earthworms. They are described as bioindicators of soil quality as they modify soil physical properties. In particular they maintain soil structure and modify soil hydrodynamic functioning (Eijsackers et al., 2005). They provide additional information about the fate of organic matter. As a consequence both nematodes and earthworms give different and therefore complementary data on soil functioning.

Several authors compared vineyard soil characteristics after inorganic and organic fertilizer application (Morlat and Chaussod, 2008; Bustamante et al., 2011) and under different grass management practices (Monteiro and Lopes, 2007; Smith et al., 2008; Steenwerth and Belina, 2008). Until now, scientific knowledge concerning the effects of organic viticulture on soil functioning is scarce, except the studies of Reeve et al. (2005), Probst et al. (2008) and Reinecke et al. (2008). There is thus a great need to evaluate if soil quality is altered by changing practices during the conversion of vineyards into organic farming. Former studies have focused on earthworms and microbial biomass (Reuter and Kubiak, 2003; Ingels et al., 2005; Whitelaw-Weckert et al., 2007), but fewer studies were conducted on nematodes as bioindicators of vineyard soil quality (Sanchez-Moreno and Ferris, 2007; Rahman et al., 2009). To our knowledge, none of this research combined several physical, chemical and biological indicators to give a complete overview of soil quality of vineyards.

In this work, we measured the long-term effects of organic viticulture by physical and chemical indicators (organic matter content, availability of major nutrients and contaminant $(\mathrm{Cu})$, bulk density) as well as by bioindicators (microbial biomass, nematodes and earthworms). With our methodology, we can then evaluate if intensive practices denoted as conventional are more damaging to soil quality and biological functions than are arguably organic practices. The present study was conducted on 24 vineyard plots: 10 were conventionally managed, while the others had different ages of conversion into organic farming $(7,11$ and 17 years).

\section{Material and methods}

\subsection{Site description, management and field plot design}

This study was conducted in May 2009 in Cruscades, which is located in the South of France, in the Languedoc-Roussillon region $\left(43^{\circ} 11^{\prime} 29.13^{\prime \prime} \mathrm{N}, 2^{\circ} 49^{\prime} 1.78^{\prime \prime} \mathrm{E} ; 26-50 \mathrm{~m}\right.$ elevation). The climate is typically Mediterranean with $14.7^{\circ} \mathrm{C}$ mean annual temperature, $600 \mathrm{~mm}$ of annual rainfall and $1380 \mathrm{~mm}$ of annual ETP PenmanMonteith (average value based on data collected from 2000 to 2010 by Météo-France). The plots did not present any slope. The soil was silty-clay, with $42 \pm 2 \%$ of silt, $36 \pm 1 \%$ of clay and $22 \pm 2 \%$ of sand.
It was calcareous ( $208 \pm 7 \mathrm{~g}$ of total $\left.\mathrm{CaCO} 3 \mathrm{~kg}^{-1}\right)$, yielding a $\mathrm{pH}$ in water of 8.3. The soil water-holding capacity was $20.6 \pm 0.5 \%(\mathrm{w} / \mathrm{w})$.

The study was conducted on 24 commercial wine grape vineyard plots whose mean area was around 1.5 ha. They presented different varieties of grape (Vitis vinifera L.) such as CabernetSauvignon, Carignan N, Chardonnay, Cinsault, Grenache N, Merlot, Mourvèdre, Pinot N and Syrah. The rootstocks were mainly R110 and R140, but Riparia and 410a were also present. The year of plantation varied from 1932 to 2003. The plantation density was comprised between 3300 and 5000 vines per hectare. Ten plots were managed according to conventional farming (Conventional) and the others according to organic farming (Organic). Five plots have been organically managed since September 2001, officially certified in 2004 (Organic7). Four plots have been organically managed since September 1997 (Organic11) and the last 5 plots since September 1991 (Organic17). These 4 sets of plots will be referred to as treatments here below. Conventional agricultural practices were identical for each treatment before the organic conversion as well as organic agricultural practices after the conversion (Table 1 ). Four representative subplots ( 5 vines $\times 4$ inter-rows) per plot were sampled. Consequently, 96 subplots were studied.

\subsection{Sampling procedure}

The sampling was conducted in springtime, a few days after mild raining events and could be considered to occur within the same time frame (on May 2009, from 4th to 15th for earthworms and from 22 nd to 28 th for soil). The soil water content was $14.7 \pm 0.3 \%$ $(\mathrm{w} / \mathrm{w})$ for earthworm sampling and $11.2 \pm 0.2 \%(\mathrm{w} / \mathrm{w})$ for soil sampling. Soil and earthworms were sampled in the $0-15 \mathrm{~cm}$ topsoil in the center of the inter-row. There were one soil and one earthworm sample per subplot. Each soil sample consisted of a composite of four subsamples, one per inter-row, taken with a gouge auger. Soil used to measure bulk density was sampled according to the cylinder method. Soil samples were sieved at $1 \mathrm{~cm}$ before biological analyses and at $2 \mathrm{~mm}$ before physical and chemical analyses. To sample earthworms, a monolith of soil of $45 \mathrm{~cm} \times 45 \mathrm{~cm}$ on $15 \mathrm{~cm}$ depth was extracted per subplot. Earthworms were sampled by the hand-sorting method and placed in alcohol solution at $75 \%$, then transferred into a $4 \%$ formaldehyde solution to be stored.

\subsection{Physical and chemical analyses}

Soil used to measure bulk density was dried at $105^{\circ} \mathrm{C}$ for 1 week and weighed rapidly thereafter (ISO 11272, 1998). Total organic carbon (TOC) and total nitrogen (N) contents were measured by dry combustion according to the ISO 10694 (1995) norm for TOC and the ISO 13878 (1998) norm for N. The effective cation exchange capacity (CEC) was determined according to the cobaltihexamine chloride method (ISO 23470, 2007). A water extract (soil:extractant ratio $1: 10$ and $2 \mathrm{~h}$ of contact) was used to determine the contents of available phosphorus $(\mathrm{P})$, potassium $(\mathrm{K})$ and copper $(\mathrm{Cu})$. The solution was centrifuged $\left(2000 \times g\right.$ during $20 \mathrm{~min}$ at $\left.20^{\circ} \mathrm{C}\right)$ and filtered at $0.2 \mu \mathrm{m}$. The P content was determined by the green malachite method (Ohno and Zibilske, 1991). The $\mathrm{K}$ and $\mathrm{Cu}$ contents were measured by flame atomic absorption spectrometry (Varian A600).

\subsection{Biological analyses}

Soil microbial biomass carbon (MB) was determined following the fumigation-extraction method (Wu et al., 1990). The organic carbon from fumigated and non-fumigated soils was measured with a total organic carbon analyzer TOC-V CSH (Shimadzu). Nematodes were extracted from $200 \mathrm{~g}$ of wet soil using the Oostenbrink 
Table 1

Agricultural practices in conventional farming and organic farming.

\begin{tabular}{|c|c|c|c|c|c|}
\hline & \multicolumn{2}{|l|}{ Soil management } & \multirow[t]{2}{*}{ Fertilization (N-P-K) } & \multirow{2}{*}{$\begin{array}{l}\text { Vine phytosanitary } \\
\text { protection }\end{array}$} & \multirow{2}{*}{$\begin{array}{l}\text { Tractor frequency } \\
\text { per year }\left(\text { year }^{-1}\right)\end{array}$} \\
\hline & Rows & Inter-rows & & & \\
\hline Conventional & $\begin{array}{l}\text { Chemical weeding } \\
\text { (glyphosate, } \\
700 \text { g ha }^{-1}, 1 \text { year }^{-1} \text { ) }\end{array}$ & $\begin{array}{l}\text { Tillage with tined tools } \\
\left(15 \mathrm{~cm} \text { depth, } 2 \text { year }^{-1}\right)\end{array}$ & $\begin{array}{l}\text { Mineral (10-10-20, } \\
\left.200 \mathrm{~kg} \mathrm{ha}^{-1}, 1 \text { year }^{-1}\right)\end{array}$ & $\begin{array}{l}\text { Synthesis and natural } \\
\left(6 \text { treatments year }^{-1}\right)\end{array}$ & 14 \\
\hline Organic & $\begin{array}{l}\text { Tillage }(10 \mathrm{~cm} \text { of depth, } \\
\left.1 \text { year }^{-1}\right)\end{array}$ & $\begin{array}{l}\text { Mouldboard ploughing } \\
\left(25 \mathrm{~cm} \text { depth, } 4 \text { year }^{-1}\right)\end{array}$ & $\begin{array}{l}\text { Compost ( } 90 \% \text { of OM) } \\
\left(9-5-0,500 \mathrm{~kg} \mathrm{ha}^{-1},\right. \\
\left.1 \text { year }^{-1}\right)\end{array}$ & $\begin{array}{l}\text { Natural }(8 \\
\left.\text { treatments year }{ }^{-1}\right)\end{array}$ & 18 \\
\hline
\end{tabular}

elutriation technique, complemented with sieving and cottonwood extraction (ISO 23611-4, 2007). Nematodes were fixed in a $4 \%$ formaldehyde solution and a representative sub-sample was mounted on glass slides for identification at high magnification ( $\times 400)$. An average of 150 nematodes per sample was identified to family level and grouped into 5 trophic groups: plant-feeders $(\mathrm{PF})$, bacterial-feeders $(\mathrm{Ba})$, fungal-feeders $(\mathrm{Fu})$, omnivores $(\mathrm{Om})$ and predators (Pr). Earthworms were gently dried before being weighed and counted. Adult and juvenile earthworms were distinguished and distributed into 2 ecological categories: endogeics and anecics.

\subsection{Statistical analyses}

An univariate approach using generalized and linear mixed models for hierarchical data (Pinherio and Bates, 2000; Bolker et al., 2009) was used to study the differences between treatments for each observed variable. Prior to the analysis and when necessary, the distribution of observed variables were adjusted to Gaussian distribution using proper transformations (square root or logarithmic). The variables describing density data belonging to nematode trophic groups and earthworm ecological categories were not normalized because they rather followed Poisson distribution. The functions lmer and glmer from the library lme4 of the R 2.11.1 software (R Development Core Team, 2011) were used to compute mixed models from variables having, respectively, Gaussian and Poisson distributions. The multiple comparisons of mean among treatments were then tested using Markov Chain Monte Carlo samples.

Based on the results of the univariate approach, a linear discriminant analysis was conducted to discriminate observations among the 4 treatments (Conventional, Organic7, Organic11 and Organic17). In order to do this, this multivariate analysis computed the best discriminant functions to differentiate objects among treatments, while minimizing variability within a treatment (Legendre and Legendre, 1998). Bulk density, total organic carbon (TOC) and total nitrogen (N) contents, soil microbial biomass carbon (MB), available phosphorus $(\mathrm{P})$, potassium $(\mathrm{K})$ and copper $(\mathrm{Cu})$ contents, effective CEC (CEC), plant-feeding (PF), bacterialfeeding ( $\mathrm{Ba}$ ), fungal-feeding ( $\mathrm{Fu}$ ), combined omnivore and predator $(\mathrm{Om}+\mathrm{Pr})$ nematode densities and endogeic earthworm density and biomass were the variables integrated in the discriminant anal- ysis. This analysis was performed using the XL-Stat software for Windows ${ }^{\circledR}$. The results were presented in the form of correlations circle of variables, distribution of the 96 observations along the two discriminant axes and confusion matrix comparing a priori (real) and $a$ posteriori (calculated) classification of observations using the cross-validation technique.

\section{Results}

\subsection{Physical and chemical parameters}

The Organic plots tended to have a higher bulk density than the Conventional plots but only bulk density of Organic11 was significantly higher than that of Conventional plots (Table 2). The TOC content significantly increased from Conventional to Organic17 (+32\%). A marked rise was measured between Organic7 and Organic11 (+15\%). Concerning the total $\mathrm{N}$ content, 2 different groups were identified. Conventional and Organic7 had significantly lower $\mathrm{N}$ content than Organic11 and Organic17. A steep decrease in available $P$ content was measured between Conventional and Organic7 $(-58 \%)$ but, thereafter, a continuous increase of available P content was noticed between Organic7 to Organic11 $(+43 \%)$ and Organic11 to Organic17 (+65\%). The available K content significantly increased from Conventional to Organic17 (+81\%). No significant difference was measured for available $\mathrm{Cu}$ content between treatments but one should note that the highest values were measured in Organic plots. The highest values of effective CEC were measured for Organic7 and Organic11. In these treatments, effective CEC was significantly higher $(+27 \%)$ in comparison with Conventional and Organic17.

\subsection{Biological parameters}

Organic11 and Organic 17 had significantly higher soil MB than Conventional and Organic7 (+34\%) (Table 3). The lowest total nematode density was measured for Conventional plots. The total nematode density was significantly higher in Organic7 $(+45 \%)$ and in Organic17 (+79\%) than in Conventional plots. The plant-feeder density was significantly higher in Organic7 (+126\%) and in Organic17 $(+187 \%)$ than in Conventional plots. Plantfeeding nematodes were dominated by facultative plant-feeders with Tylenchidae family (data not shown). Among obligate plant-

Table 2

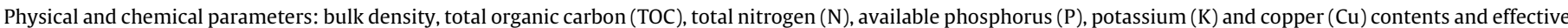
cation exchange capacity (CEC) in conventional farming (Conventional) and organic farming for 7 years (Organic7), 11 years (Organic11) and 17 years (Organic17).

\begin{tabular}{|c|c|c|c|c|c|c|c|}
\hline & Bulk density $\left(\mathrm{g} \mathrm{cm}^{-3}\right)^{*}$ & $\mathrm{TOC}\left(\mathrm{mg} \mathrm{g}^{-1}\right)^{*}$ & $\mathrm{~N}\left(\mathrm{mg} \mathrm{g}^{-1}\right)^{*}$ & $\mathrm{P}\left(\mathrm{mg} \mathrm{kg}^{-1}\right)^{*}$ & $\mathrm{~K}\left(\mathrm{mg} \mathrm{kg}^{-1}\right)^{¥}$ & $\mathrm{Cu}\left(\mathrm{mg} \mathrm{kg}^{-1}\right)^{\mathrm{ns}}$ & $\mathrm{CEC}\left(\mathrm{cmol}^{+} \mathrm{kg}^{-1}\right)^{*}$ \\
\hline Conventional & $1.21 \pm 0.03 \mathrm{~b}$ & $10.2 \pm 0.3 c$ & $1.00 \pm 0.02 b$ & $1.06 \pm 0.12 \mathrm{a}$ & $27 \pm 3 c$ & $0.22 \pm 0.03 \mathrm{a}$ & $16.3 \pm 0.5 b$ \\
\hline Organic7 & $1.31 \pm 0.01 \mathrm{ab}$ & $10.8 \pm 0.4 \mathrm{bc}$ & $1.01 \pm 0.03 \mathrm{~b}$ & $0.45 \pm 0.04 b$ & $30 \pm 3 b c$ & $0.35 \pm 0.07 \mathrm{a}$ & $19.9 \pm 0.7 \mathrm{a}$ \\
\hline Organic11 & $1.41 \pm 0.02 \mathrm{a}$ & $12.4 \pm 0.4 \mathrm{ab}$ & $1.25 \pm 0.05 \mathrm{a}$ & $0.64 \pm 0.04 \mathrm{ab}$ & $45 \pm 5 \mathrm{ab}$ & $0.34 \pm 0.06 \mathrm{a}$ & $20.7 \pm 0.8 \mathrm{a}$ \\
\hline Organic17 & $1.29 \pm 0.01 \mathrm{ab}$ & $13.5 \pm 0.5 \mathrm{a}$ & $1.36 \pm 0.04 \mathrm{a}$ & $1.05 \pm 0.06 \mathrm{a}$ & $49 \pm 5 a$ & $0.39 \pm 0.07 \mathrm{a}$ & $15.7 \pm 0.4 b$ \\
\hline
\end{tabular}

Means \pm standards errors are presented. Means differing significantly are denoted with different lowercase letters; ns, not significant.

${ }^{*}$ Threshold significant at $95 \%$.

$¥$ Threshold significant at $90 \%$. 
Table 3

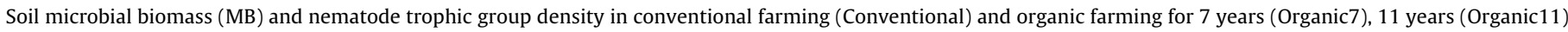
and 17 years (Organic17).

\begin{tabular}{|c|c|c|c|c|c|c|}
\hline & \multirow{2}{*}{$\begin{array}{l}\text { Microorganisms } \\
\operatorname{MB}\left(\mu g \mathrm{Cg}^{-1}\right)^{¥}\end{array}$} & \multicolumn{5}{|c|}{ Nematofauna (ind. (100 g dry soil) $)^{-1}$ ) } \\
\hline & & Plant-feeders ${ }^{*}$ & Bacterial-feeders $^{\text {ns }}$ & Fungal-feeders ${ }^{¥}$ & Omnivores-predators ${ }^{¥}$ & Total $^{¥}$ \\
\hline Conventional & $77 \pm 7 b$ & $210 \pm 17 c$ & $402 \pm 29 a$ & $212 \pm 15 b$ & $112 \pm 12 b$ & $936 \pm 49 c$ \\
\hline Organic7 & $73 \pm 3 b$ & $474 \pm 62 \mathrm{ab}$ & $422 \pm 36 a$ & $303 \pm 38 a$ & $156 \pm 20 \mathrm{a}$ & $1355 \pm 115 \mathrm{ab}$ \\
\hline Organic11 & $100 \pm 5 \mathrm{a}$ & $403 \pm 69 b$ & $440 \pm 55 a$ & $303 \pm 37 a$ & $101 \pm 17 b$ & $1248 \pm 137 \mathrm{bc}$ \\
\hline Organic17 & $101 \pm 4 \mathrm{a}$ & $603 \pm 62 a$ & $541 \pm 60 a$ & $417 \pm 51 \mathrm{a}$ & $113 \pm 13 b$ & $1672 \pm 143 \mathrm{a}$ \\
\hline
\end{tabular}

Means \pm standards errors are presented. Means differing significantly are denoted with different lowercase letters; ns, not significant.

* Threshold significant at $95 \%$.

$¥$ Threshold significant at $90 \%$.

feeders, Paratylenchus sp. and Tylenchorynchus sp. dominated and almost no Xiphinema sp. were found whatever the treatment, just 7.5 and 12.1 ind. (100 g dry soil $)^{-1}$ for 2 samples (data not shown). No significant difference was measured for bacterialfeeder densities between treatments. However, the lowest density was observed for Conventional plots. The fungal-feeder density increased from Conventional to Organic17. It was significantly higher in Organic7 (+43\%) and in Organic17 (+97\%) than in Conventional plots. The combined density of omnivores and predators was significantly higher $(+44 \%)$ in Organic7 than in other treatments.

There were many samples without earthworms in all the treatments, and especially in the Organic plots (Table 4). The total earthworm density was significantly higher in Conventional than in Organic plots $(-44 \%$ between Conventional and Organic7 and $-55 \%$ between Conventional and Organic17). Endogeics were the most represented (more than $85 \%$ of total density) compared to the anecics in both Conventional and Organic plots. The anecic density was low whatever the treatment and not significantly different between treatments. The highest biomass of earthworms was observed in the Conventional plots. Contrary to the density, the biomass was mainly represented by the anecics.

\subsection{Discriminant analysis}

The discriminant analysis (Fig. 1 and Table 5) was significant at $\alpha=0.001$ according to the Wilks test and each discriminant axis explained a significant portion of the overall variance of the database $(p<0.01)$. The first two discriminant functions explained $93 \%$ of the dataset variability (Fig. 1A). The first axis explained $68 \%$ of the dataset variability and was mainly defined by total N and TOC contents, plant-feeding nematode density, available K content and fungal-feeding nematode density. The axis 2 contributed $25 \%$ of the dataset variability and was correlated to effective CEC and available $P$ content. The distribution of observations along the 2 axes showed a clear discrimination of the 4 treatments (Fig. 1B). The first axis clearly discriminated the 4 treatments and therefore, a gradient starting from Conventional to Organic17 was found along this axis. On the other hand, the second axis was less discriminant as it only discriminated Conventional and Organic17 from Organic7 and Organic11. Some overlaps were observed between treatments and were associated to the variability of observations in a given treatment. The confusion matrix (Table 5) compared the classification of plots predicted by the model of discriminant analysis and the real classification constituted from experimental plot design. The confusion matrix showed that the discriminant analysis successfully classified $79 \%$ of the 96 observations. The a posteriori classification of Conventional and Organic17 plots were respectively correct at a rate of 88 and $90 \%$ whereas, Organic7 and Organic11 plots were correctly classified, respectively at a rate of $75 \%$ and $55 \%$.

\section{Discussion}

\subsection{Soil quality indicators to study the transition to organic farming}

This study was conducted on commercial vineyards. Fourteen plots which have been organically managed for 7,11 and 17 years were compared to 10 conventionally managed plots. We analysed the long-term effects of organic management on vineyard soil quality determined by physical, chemical and also biological indicators. Measurements on grape production were not included to define soil quality because the diversity of plant material would not have given reliable data to compare the different treatments. As reviewed by Bastida et al. (2008), the multiparametric indices are a promising tool to objectively describe the changes of soil quality but the weighting of different functions is subjective and does not depend on statistical (objective) method. In this study, our statistical approach was different because we used a combination of statistical tools that clearly distinguish the four treatments which organized themselves along the first axis, defining a gradient starting from Conventional to Organic17. Indeed, no significant difference appeared before 11 years of organic farming for total organic carbon (TOC), total nitrogen (N) and available potassium (K) contents, soil microbial biomass (MB) and fungal-feeding nematode density $(\mathrm{Fu})$. However, other soil indicators, such as available P content rapidly decreased after conversion. Some authors, such as Martin et al. (2007), explained such a trend as an exhaustion of available $P$ pools built up from successive mineral $P$ fertilizers. Afterwards, we observed an increase of available P content as reported by Garcia-Ruiz et al. (2009) and Liu et al. (2007) on differ-

Table 4

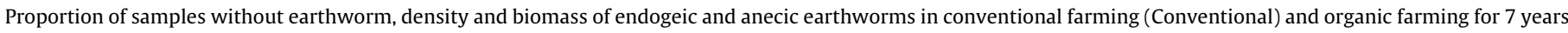
(Organic7), 11 years (Organic11) and 17 years (Organic17).

\begin{tabular}{|c|c|c|c|c|c|c|c|}
\hline & \multirow[t]{2}{*}{ Samples without earthworm (\%) } & \multicolumn{3}{|c|}{ Density (ind $\mathrm{m}^{-2}$ ) } & \multicolumn{3}{|c|}{ Biomass $\left(\mathrm{g} \mathrm{m}^{-2}\right)$} \\
\hline & & Endogeics $¥$ & Anecics ${ }^{\mathrm{ns}}$ & Total $^{¥}$ & Endogeics $^{\mathrm{ns}}$ & Anecics ${ }^{\mathrm{ns}}$ & Total $^{\text {ns }}$ \\
\hline Conventional & 45 & $12.5 \pm 2.6 \mathrm{a}$ & $1.1 \pm 0.5 \mathrm{a}$ & $13.6 \pm 2.6 \mathrm{a}$ & $4.5 \pm 1.1 \mathrm{a}$ & $15.5 \pm 8.9 a$ & $19.9 \pm 9.1 \mathrm{a}$ \\
\hline Organic7 & 75 & $6.9 \pm 5.5 b$ & $0.7 \pm 0.7 \mathrm{a}$ & $7.6 \pm 5.5 b$ & $0.6 \pm 0.6 \mathrm{a}$ & $1.1 \pm 1.1 \mathrm{a}$ & $1.8 \pm 1.3 \mathrm{a}$ \\
\hline Organic11 & 75 & $6.1 \pm 4.0 \mathrm{~b}$ & $0.6 \pm 0.6 \mathrm{a}$ & $6.7 \pm 4.0 \mathrm{~b}$ & $1.0 \pm 0.9 \mathrm{a}$ & $8.1 \pm 8.1 \mathrm{a}$ & $9.0 \pm 8.1 \mathrm{a}$ \\
\hline Organic17 & 60 & $4.4 \pm 2.0 \mathrm{~b}$ & $1.7 \pm 0.9 \mathrm{a}$ & $6.1 \pm 2.1 \mathrm{~b}$ & $0.3 \pm 0.1 \mathrm{a}$ & $11.3 \pm 7.0 \mathrm{a}$ & $11.7 \pm 7.0 \mathrm{a}$ \\
\hline
\end{tabular}

Means \pm standards errors are presented. Means differing significantly are denoted with different lowercase letters; ns, not significant.

$¥$ Threshold significant at $90 \%$. 
A
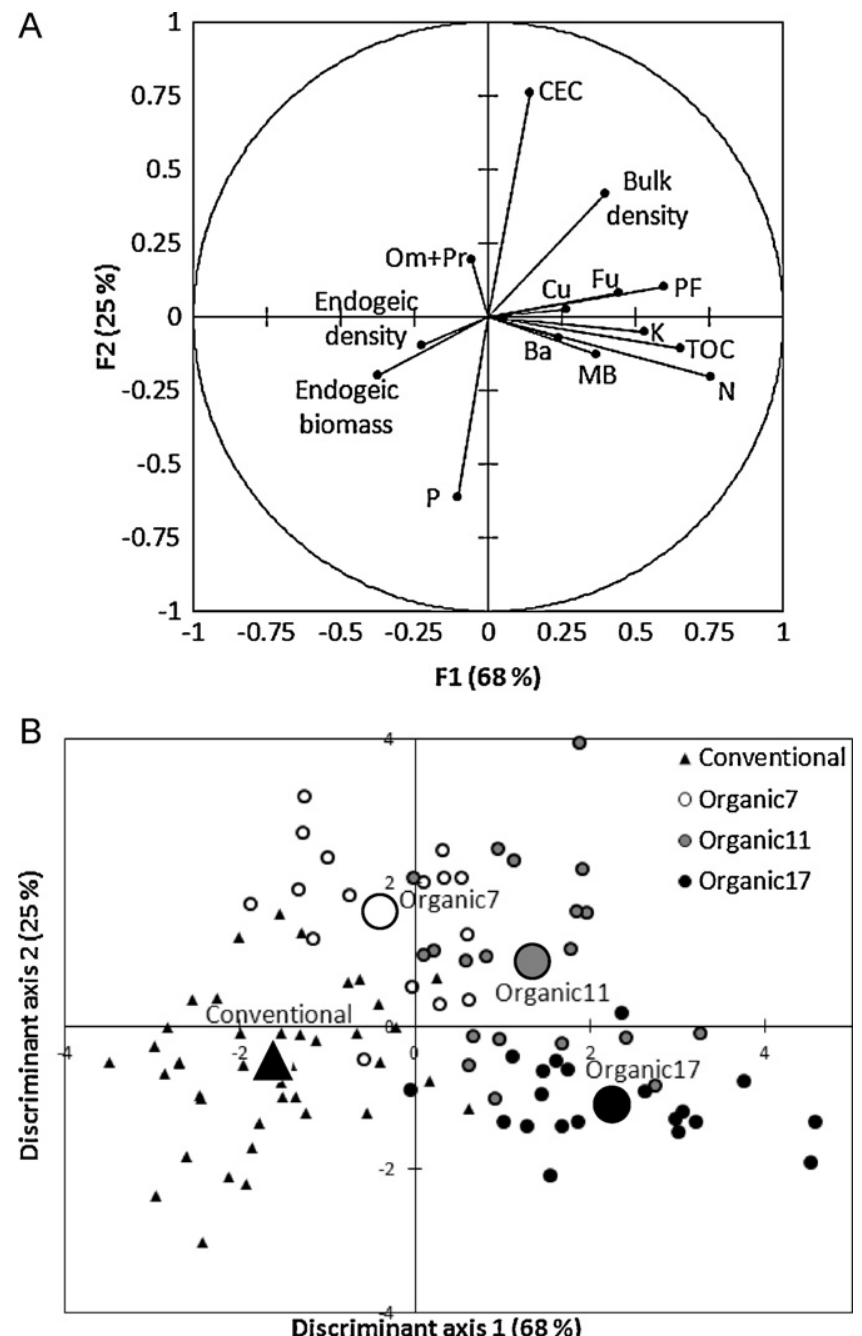

Fig. 1. Discriminant analysis performed on physical, chemical and biological parameters for conventional farming (Conventional) and organic farming for 7 years (Organic7), 11 years (Organic11) and 17 years (Organic17). (A) Correlations circle of variables: bulk density, total organic carbon (TOC), total nitrogen (N), available phosphorus $(\mathrm{P})$, potassium $(\mathrm{K})$ and copper $(\mathrm{Cu})$ contents, effective cation exchange capacity (CEC), soil microbial biomass (MB), density of plant-feeding (PF), bacterialfeeding $(\mathrm{Ba})$, fungal-feeding $(\mathrm{Fu})$, omnivore and predator $(\mathrm{Om}+\mathrm{Pr})$ nematodes and density and biomass of endogeic earthworms. (B) Distribution of the 96 observations and of the centroids (prominent symbols) of each treatment along the 2 discriminant axes.

ent crops. Conversely, available K content increased progressively from Conventional to Organic17 whereas Gosling and Shepherd (2005) observed $\mathrm{K}$ was significantly higher in the conventional fields than in the low fertility organic fields. One should note that the quantity of compost applied was too low to explain the observed trends for P and $\mathrm{K}$ ( $25 \mathrm{~kg} \mathrm{P} \mathrm{ha}^{-1} \mathrm{year}^{-1}$ and no K, Table 1 ). Previous studies have shown that microorganisms release organic acids which can increase the availability of $\mathrm{P}$ (Arcand and Schneider,
2006) and K (Basak and Biswas, 2009). Phosphatases excreted by microorganisms, and more particularly fungi, have also the ability to mineralize organic P (Rodriguez and Fraga, 1999). Thus, the increase of microbial biomass after organic conversion and activities of some microorganisms could explain why after 7 years of organic farming, the available $\mathrm{P}$ and $\mathrm{K}$ contents increased. The total nematode density, especially plant-feeders (PF) and total earthworm density, especially endogeic density responded more sharply and quickly to the organic conversion. Garcia-Ruiz et al. (2009) did the same observation for the plant-feeder density in one site of olive groves after 7-8 years of organic practices. In our case, plant-feeders that increased in density were mainly the facultative plant-feeders Tylenchidae and phytoparasitics, Tylenchorynchus sp. Xiphinema sp., grapevine fanleaf virus vector (GFLV) were almost absent in each treatment. However, it is known that the highest density of Xiphinema sp. occurred at $40-110 \mathrm{~cm}$ depth and yet we sampled it in the $0-15 \mathrm{~cm}$ topsoil (Villate et al., 2008). For earthworm density, Scullion et al. (2007) observed some positive effects after 10 years of organic farming on grass-arable rotations. Gradual changes of soil properties in converting plots into organic farming have been measured by several authors and discussed by Martini et al. (2004). The other studied indicators did not present any change and should be considered as not sensitive enough to monitor the conversion to organic viticulture in these pedo-climatic conditions. So, organic matter, available $\mathrm{P}$ and $\mathrm{K}$, microbial biomass, nematodes and earthworms could be considered as a basis to a guideline to best transition strategies in vineyards.

\subsection{Effects of organic farming on soil organisms}

In organic farming, plant nutrition is based on the mineralization of organic matter by soil organisms. Several authors reported negative effects of Cu on soil organisms (Wightwick et al., 2010). We observed, as Beni and Rossi (2009), trends of higher available $\mathrm{Cu}$ contents in Organic treatments than in Conventional ones. As a matter of facts, $\mathrm{Cu}$ salts are the only efficient fungicides against downy mildew, allowed in organic farming. Furthermore, Brun et al. (2001) showed Cu accumulates in the upper layers of soils. However in our study, we did not observe significant increase of available $\mathrm{Cu}$ after organic conversion. This might be related to the method that we used for measuring Cu availability. Michaud et al. (2007) have shown that in calcareous soils contaminated by $\mathrm{Cu}$ fungicides, water-extractable $\mathrm{Cu}$ varied little, compared to total soil $\mathrm{Cu}$, or EDTA-extractable Cu.

Generally, grass cover and applications of organic matter have positive effects on earthworms in vineyards (Peres et al., 1998; Paoletti, 1999; Eisenhauer et al., 2009). However, we measured the lowest density and biomass of earthworms in Organic plots. The density of anecics was very low in all treatments but it was certainly underestimated. Actually, the hand-sorting method without prior application of an expellant (such as mustard or formaldehyde solution) did not allow to sample larger earthworms, such as anecics, which can rapidly escape into deeper soil layers (Pelosi et al., 2009). However, the hand-sorting is appropriate for endogeic and their density strongly decreased between Conventional and

Table 5

Confusion matrix comparing a priori (real) and a posteriori (calculated) classification of observations using the cross-validation technique.

\begin{tabular}{|c|c|c|c|c|c|}
\hline & \multicolumn{4}{|c|}{ A posteriori classification } & \multirow[t]{2}{*}{ Correct classifications (\%) } \\
\hline & Conventional & Organic7 & Organic11 & Organic17 & \\
\hline \multicolumn{6}{|c|}{ A priori classification } \\
\hline Conventional & 35 & 3 & 2 & 0 & 88 \\
\hline Organic7 & 3 & 12 & 1 & 0 & 75 \\
\hline Organic11 & 0 & 3 & 11 & 6 & 55 \\
\hline Organic17 & 1 & 0 & 1 & 18 & 90 \\
\hline
\end{tabular}


Organic7. The tillage which was more frequent to control weeds under organic management could also explain these observations. Several authors highlighted negative effects of tillage on earthworm density and biomass (Emmerling, 2001; Paoletti, 1999 on different crops). Furthermore, with the organic conversion, the shallow tillage was replaced by a deeper mouldboard ploughing. Short-term studies ( 3 and 6 years) of Metzke et al. (2007) and Peigné et al. (2009) on different tillage systems under organic annual crop farming did not observe higher earthworm density or biomass under shallow tillage in comparison with mouldboard ploughing. However, we could hypothesize that mouldboard ploughing has long-term negative effect on earthworms. Villenave et al. (2009) demonstrated that tillage also tends to disturb omnivore and predator nematodes. In the same way, we did not measure any modification of the densities of these nematodes with organic farming and their low densities in every plot indicated a simple and short soil micro-food web in all these vineyards (Ferris et al., 2001). Soil compaction, as evaluated by the measure of bulk density, was higher in Organic plots. This was the consequence of the increase of the traffic for tillage and phytosanitary treatments in organic management. Bouwman and Arts (2000) observed a decrease of free-living nematode density in a heavily compacted soil compared with a slightly compacted soil. They explained that nematodes reacted negatively to the decreased pore space habitats due to soil compaction. In our case, bacterial and fungal-feeding nematode density was globally higher in Organic plots despite an increased bulk density. Hansen (1996) and Hansen and Engelstad (1999) showed that soil compaction had negative effects on earthworms. So, soil compaction could explain, with ploughing, the decrease of earthworm density that we observed in organic viticulture. More globally, agricultural practices in organic conversion cause some damage on soil organisms.

\subsection{Organic matter, microbial biomass and nematodes}

The soil organic matter plays essential roles in soil functioning and it can be considered as the keystone of soil management under organic farming. Under Organic plots, we measured higher TOC contents. Many authors observed the same positive effect of organic farming as Briar et al. (2007) on different annual crops and Vestberg et al. (2009) on strawberry crops. The sole application of compost ( $261 \mathrm{~kg}$ of organic carbon ha ${ }^{-1}$ year $^{-1}$ ) would lead to a content of $11.2 \mathrm{mg}$ of $\mathrm{TOC}^{-1}$ of soil after 17 years of organic farming whereas we measured it at $13.5 \mathrm{mgg}^{-1}$. Thus, the more abundant grass cover in Organic treatments contributed certainly in the increase of TOC contents and microbial biomass as observed by Potthoff et al. (2006). Organic matter constitutes a source of nutrients for microorganisms (Calbrix et al., 2007) which increased after the conversion into organic farming and root-exudates are known too to stimulate microbial growth (Bouwman and Arts, 2000; Whitelaw-Weckert et al., 2007). In the same way, Rahman et al. (2009) showed positive effects of grass cover on the density of plant-feeding and microbivorous nematodes which agreed with our results. An increase of plant-feeding nematodes intensifies root $\mathrm{C}$ fluxes activating microbial biomass from the rhizosphere and microbivorous nematodes stimulate microorganisms (Denton et al., 1999). Conversely, as there were more microorganisms in Organic plots, we consistently found more fungal-feeding nematode density in organic plots, which is in line with Ferris et al. (1996), Villenave et al. (2004) and Villenave et al. (2010). However, only an increasing trend was observed for bacterial-feeding nematode density in Organic plots. The nematodes are good indicators of soil decomposition pathway (Ferris et al., 2004). The bacterialfeeders/fungal-feeders ratio decreased with organic farming, as observed by Mc Sorley and Frederick (1999). So, the decomposition pathway becomes dominated by fungi under Organic plots in com- parison with Conventional plots. The increase of fungi after organic conversion was also observed by different authors as Gryndler et al. (2006) for arbuscular mycorrhizal fungi. Thus, the application of compost and the presence of a grass cover on Organic plots led to increase soil organic matter, microbial biomass and nematode density, especially plant-feeders and fungal-feeders whereas ratio bacteria/fungi decreased.

\section{Conclusion}

Through our experimental design, we studied long-term effects of different changes of agricultural practices inherent to organic viticulture on soil quality. In this study, we have demonstrated that a transition period of 7-11 years, depending on the considered indicator, was needed to clearly separate Conventional and Organic farming practices in Southern French vineyards. Apart from classical sensitive indicators used to study organic transition like organic matter content, soil microbial biomass, or bulk density, the easy-touse chemical available $\mathrm{P}$ and $\mathrm{K}$ contents should also be considered as sensitive indicators. Moreover, our results address the important question of $\mathrm{P}$ and $\mathrm{K}$ mining with organic practices during transition period. However afterwards, the increase of soil organic matter and related biological activities could partly counteract the observed decrease during the transition period. According to our results, the utilization of soil nematodes as bioindicators of soil quality shall be promoted. Indeed, the study of microbivorous provided some information about microbial biomass and bacteria/fungi ratio. As for omnivore and predator nematodes, they were reliable indicators of environmental perturbations. Despite the diversity of indicators, we have highlighted the difficulty to show the benefits of organic farming on global soil quality in this particular pedoclimatic area, and for the set of farming practices that were investigated.

\section{Acknowledgements}

We thank Louis Fabre, Xavier Sabouraud, Regis Loevenbruck, Jean-Jacques Loze and Gérard Pélissa for allowing us to analyse their vineyards. We also thank Hervé Aholoukpé, Hubert Alcin, Didier Arnal, Didier Blavet, Georg Carlsson, Benoît Cloutier-Hurteau, Cathy Coll, Gabrielle Daudin, Fan Deng, Marney Isaac, Sylvia Julien, Siham Khoulassa, Ernest Kouakoua, Rym Maougal, Aurélie Metay and Emilie Russello for their help in earthworm sampling. Special thanks go to Jean-Pierre Barthès for his expert advice on soils, Inès Sneessens and Malalatiana Razafindrakoto for her help in the laboratory analyses, and Julien Papaïx, Philippe Deleporte and Benoît CloutierHurteau for assistance with statistics. We gratefully acknowledge Terri Andon for carefully reading the manuscript and English revision.

Patrice Coll's PhD grant was provided by the Agence de l'Environnement et de la Maîtrise de l'Energie (ADEME, France) and by Montpellier SupAgro (France). This work was financially supported by the INRA AIDY project (Analyse Intégrée de la DYnamique des systèmes biophysiques, techniques et de décision lors de la conversion à la viticulture biologique).

\section{References}

AgenceBIO, 2002. L'agriculture biologique - Chiffres clés, Broché, Paris.

AgenceBIO, 2009. L'agriculture biologique - Chiffres clés, La documentation Française, Paris.

Arcand, M.M., Schneider, K.D., 2006. Plant- and microbial-based mechanisms to improve the agronomic effectiveness of phosphate rock: a review. An. Acad. Bras. Cienc. 78, 791-807.

Basak, B.B., Biswas, D.R., 2009. Influence of potassium solubilizing microorganism (Bacillus mucilaginosus) and waste mica on potassium uptake dynamics by sudan grass (Sorghum vulgare Pers.) grown under two Alfisols. Plant Soil 317, 235-255.

Bastida, F., Zsolnay, A., Hernández, T., García, C., 2008. Past, present and future of soil quality indices: a biological perspective. Geoderma 147, 159-171. 
Beni, C., Rossi, G., 2009. Conventional and organic farming: estimation of some effects on soil, copper accumulation and wine in a Central Italy vineyard. Agrochimica 53, 145-159.

Bispo, A., Blanchart, E., Delmas, A.B., Laval, K., 2011. Icateurs de la qualité des sols. In: Girard, M.C., Walter, C., Rémy, J.C., Berthelin, J., Morel, J.L. (Eds.), Sols et Environnement. , 2e édition. Dunod éditions, Paris, pp. 509-527.

Bolker, B.M., Brooks, M.E., Clark, C.J., Geange, S.W., Poulsen, J.R., Stevens, M.H.H., White, J.S.S., 2009. Generalized linear mixed models: a practical guide for ecology and evolution. Trends Ecol. Evol. 24, 127-135.

Bongers, T., Ferris, H., 1999. Nematode community structure as a bioindicator in environmental monitoring. Trends Ecol. Evol. 14, 224-228.

Bouwman, L.A., Arts, W.B.M., 2000. Effects of soil compaction on the relationships between nematodes, grass production and soil physical properties. Appl. Soil Ecol. 14, 213-222.

Briar, S.S., Grewal, P.S., Somasekhar, N., Stinner, D., Miller, S.A., 2007. Soil nematode community, organic matter, microbial biomass and nitrogen dynamics in field plots transitioning from conventional to organic management. Appl. Soil Ecol. 37, 256-266.

Brun, L.A., Maillet, J., Hinsinger, P., Pepin, M., 2001. Evaluation of copper availability to plants in copper-contaminated vineyard soils. Environ. Pollut. 111, 293-302.

Bustamante, M.A., Said-Pullicino, D., Agullo, E., Andreu, J., Paredes, C., Moral, R., 2011. Application of winery and distillery waste composts to a Jumilla (SE Spain) vineyard: effects on the characteristics of a calcareous sandy-loam soil. Agric. Ecosyst. Environ. 140, 80-87.

Calbrix, R.L., Barray, S., Chabrerie, O., Fourrie, L., Laval, K., 2007. Impact of organic amendments on the dynamics of soil microbial biomass and bacterial communities in cultivated land. Appl. Soil Ecol. 35, 511-522.

Chaignon, V., Sanchez-Neira, I., Herrmann, P., Jaillard, B., Hinsinger, P., 2003. Copper bioavailability and extractability as related to chemical properties of contaminated soils from a vine-growing area. Environ. Pollut. 123, $229-238$

Coulouma, G., Boizard, H., Trotoux, G., Lagacherie, P., Richard, G., 2006. Effect of deep tillage for vineyard establishment on soil structure: a case study in Southern France. Soil Tillage Res. 88, 132-143.

Denton, C.S., Bardgett, R.D., Cook, R., Hobbs, P.J., 1999. Low amounts of root herbivory positively influence the rhizosphere microbial community in a temperate grassland soil. Soil Biol. Biochem. 31, 155-165.

Doran, J.W., Parkin, T.B., 1994. Defining and Assessing Soil Quality, SSSA Spec. Publ. No. 35. Soil Sci. Soc. Am., Inc. and Am. Soc. Agron., Inc., Madison, WI.

Eijsackers, H., Beneke, P., Maboeta, M., Louw, J.P.E., Reinecke, A.J., 2005. The implications of copper fungicide usage in vineyards for earthworm activity and resulting sustainable soil quality. Ecotoxicol. Environ. Saf. 62, 99-111.

Eisenhauer, N., Milcu, A., Sabais, A.C.W., Bessler, H., Weigelt, A., Engels, C., Scheu, $S$, 2009. Plant community impacts on the structure of earthworm communities depend on season and change with time. Soil Biol. Biochem. 41, 2430-2443.

Emmerling, C., 2001. Response of earthworm communities to different types of soil tillage. Appl. Soil Ecol. 17, 91-96.

Ferris, H., Venette, R.C., Lau, S.S., 1996. Dynamics of nematode communities in tomatoes grown in conventional and organic farming systems, and their impact on soil fertility. Appl. Soil Ecol. 3, 161-175.

Ferris, H., Bongers, T., de Goede, R.G.M., 2001. A framework for soil food web diagnostics: extension of the nematode faunal analysis concept. Appl. Soil Ecol. 18 13-29.

Ferris, H., Venette, R.C., Scow, K.M., 2004. Soil management to enhance bacterivore and fungivore nematode populations and their nitrogen mineralisation function. Appl. Soil Ecol. 25, 19-35.

Franzle, O.,2006. Complex bioindication and environmental stress assessment. Ecol. Indic. 6, 114-136.

Garcia-Ruiz, R., Ochoa, V., Vinegla, B., Hinojosa, M.B., Pena-Santiago, R., Liebanas, G., Linares, J.C., Carreira, J.A., 2009. Soil enzymes, nematode community and selected physico-chemical properties as soil quality indicators in organic and conventional olive oil farming: Influence of seasonality and site features. Appl. Soil Ecol. 41, 305-314.

Gosling. P., Shepherd, M., 2005. Long-term changes in soil fertility in organic arable farming systems in England, with particular reference to phosphorus and potassium. Agric. Ecosyst. Environ. 105, 425-432.

Gryndler, M., Larsen, J., Hrselova, H., Rezacova, V., Gryndlerova, H., Kubat, J., 2006. Organic and mineral fertilization, respectively, increase and decrease the development of external mycelium of arbuscular mycorrhizal fungi in a long-term field experiment. Mycorrhiza 16, 159-166.

Hansen, S., 1996. Effects of manure treatment and soil compaction on plant production of a dairy farm system converting to organic farming practice. Agric. Ecosyst. Environ. 56, 173-186.

Hansen, S., Engelstad, F., 1999. Earthworm populations in a cool and wet district as affected by tractor traffic and fertilisation. Appl. Soil Ecol. 13, 237-250.

Haynes, R.J., 1999. Labile organic matter fractions and aggregate stability under short-term, grass-based leys. Soil Biol. Biochem. 31, 1821-1830.

Huber, S., Prokop, G., Arrouays, D., Banko, G., Bispo, A., Jones, R.J.A., Kibblewhite, M.G., Lexer, W., Möller, A., Rickson, R.J., Shishkov, T., Stephens, M., Toth, G. van den Akker, J.J.H., Varallyay, G., Verheijen, F.G.A., Jones, A.R., 2008. Environmental Assessment of Soil for Monitoring: Volume I Indicators \& Criteria, EUR 23490 EN/1. Office for the Official Publications of the European Communities, Luxembourg.
Ingels, C.A., Scow, K.M., Whisson, D.A., Drenovsky, R.E.,2005. Effects of cover crops on grapevines, yield, juice composition, soil microbial ecology, and gopher activity. Am. J. Enol. Vitic. 56, 19-29.

ISO 10694, 1995. Soil quality-determination of organic and total carbon after dry combustion (elementary analysis)

ISO 11272, 1998. Soil quality-determination of dry bulk density.

ISO 13878,1998 . Soil quality-determination of total nitrogen content by dry combustion (elementary analysis).

ISO 23470, 2007. Soil quality-determination of effective cation exchange capacity (CEC) and exchangeable cations using a hexamminecobalt trichloride solution.

ISO 23611-4, 2007. Soil quality-sampling of soil invertebrates-part 4: sampling, extraction and identification of soil-inhabiting nematodes.

Komarek, M., Cadkova, E., Chrastny, V., Bordas, F., Bollinger, J.C., 2010. Contamination of vineyard soils with fungicides: a review of environmental and toxicological aspects. Environment International 36, 138-151.

Le Bissonnais, Y., Blavet, D., De Noni, G., Laurent, J.Y., Asseline, J., Chenu, C., 2007. Erodibility of Mediterranean vineyard soils: relevant aggregate stability methods and significant soil variables. Eur. J. Soil Sci. 58, 188-195.

Legendre, P., Legendre, L., 1998. Numerical ecology, 3rd English edition. Elsevier Amsterdam.

Liu, B., Tu, C., Hu, S.J., Gumpertz, M., Ristaino, J.B., 2007. Effect of organic, sustainable, and conventional management strategies in grower fields on soil physical, chemical, and biological factors and the incidence of Southern blight. Appl. Soil Ecol. 37, 202-214

Martin, R.C., Lynch, D.H., Frick, B., van Straaten, P., 2007. Phosphorus status on Canadian organic farms. J. Sci. Food Agric. 87, 2737-2740.

Martinez-Casasnovas, J.A., Ramos, M.C., 2009. Soil alteration due to erosion, ploughing and levelling of vineyards in north east Spain. Soil Use Manage. 25, 183-192.

Martini, E.A., Buyer, J.S., Bryant, D.C., Hartz, T.K., Denison, R.F., 2004. Yield increases during the organic transition: improving soil quality or increasing experience? Field Crop Res. 86, 255-266.

Mc Sorley, R., Frederick, J.J., 1999. Nematode population fluctuations during decomposition of specific organic amendments. J. Nematol. 31, 37-44.

Metzke, M., Potthoff, M., Quintern, M., Hess, J., Joergensen, R.G., 2007. Effect of reduced tillage systems on earthworm communities in a 6-year organic rotation. Eur. J. Soil Biol. 43, S209-S215.

Michaud, A.M., Bravin, M.N., Galleguillos, M., Hinsinger, P., 2007. Copper uptake and phytotoxicity as assessed in situ for durum wheat (Triticum turgidum durum L.) cultivated in Cu-contaminated, former vineyard soils. Plant Soil 298 99-111

Monteiro, A., Lopes, C.M., 2007. Influence of cover crop on water use and performance of vineyard in Mediterranean Portugal. Agric. Ecosyst. Environ. 121, 336-342.

Morlat, R., Chaussod, R., 2008. Long-term additions of organic amendments in a Loire valley vineyard. I. Effects on properties of a calcareous sandy soil. Am. J. Enol Vitic. 59, 353-363.

Neher, D.A., 2001. Role of nematodes in soil health and their use as indicators. J Nematol. 33, 161-168.

Ohno, T., Zibilske, L.M., 1991. Determination of low concentrations of phosphorus in soil extracts using malachite green. Soil Sci. Soc. Am. J. 55, 892-895.

Paoletti, M.G., 1999. The role of earthworms for assessment of sustainability and as bioindicators. Agric. Ecosyst. Environ. 74, 137-155.

Paul, E.A., Clark, M.F., 1996. Soil Microbiology and Biochemistry. Academic Press, San Diego.

Peigné, J., Cannavaciuolo, M., Gautronneau, Y., Aveline, A., Giteau, J.L., Cluzeau, D. 2009. Earthworm populations under different tillage systems in organic farming. Soil Tillage Res. 104, 207-214.

Pelosi, C., Bertrand, M., Capowiez, Y., Boizard, H., Roger-Estrade, J., 2009. Earthworm collection from agricultural fields: comparisons of selected expellants in presence/absence of hand-sorting. Eur. J. Soil Biol. 45, 176-183.

Peres, G., Cluzeau, D., Curmi, P., Hallaire, V., 1998. Earthworm activity and soil structure changes due to organic enrichments in vineyard systems. Biol. Fertil. Soils 27, 417-424.

Pinheiro, J.C., Bates, D.M., 2000. Mixed-Effects Models in S and S-plus. Springer, New York.

Potthoff, M., Steenwerth, K.L., Jackson, L.E., Drenovsky, R.E., Scow, K.M., Joergensen R.G., 2006. Soil microbial community composition as affected by restoration practices in California grassland. Soil Biol. Biochem. 38, 1851-1860.

Probst, B., Schuler, C., Joergensen, R.G., 2008. Vineyard soils under organic and conventional management-microbial biomass and activity indices and their relation to soil chemical properties. Biol. Fertil. Soils 44, 443-450.

Rahman, L., Whitelaw-Weckert, M.A., Hutton, R.J., Orchard, B., 2009. Impact of floor vegetation on the abundance of nematode trophic groups in vineyards. Appl. Soil Ecol. 42, 96-106.

Reeve, J.R., Carpenter-Boggs, L., Reganold, J.P., York, A.L., McGourty, G., McCloskey L.P., 2005. Soil and winegrape quality in biodynamically and organically managed vineyards. Am. J. Enol. Vitic. 56, 367-376.

Reganold, J.P., Elliott, L.F., Unger, Y.L., 1987. Long-term effects of organic and conventional farming on soil-erosion. Nature 330, 370-372.

Reinecke, A.J., Albertus, R.M.C., Reinecke, S.A., Larink, O., 2008. The effects of organic and conventional management practices on feeding activity of soil organisms in vineyards. Afr. Zool. 43, 66-74

Reuter, S., Kubiak, R., 2003. Soil Management Systems to Support Soil Microbia Biomass in Vineyards. Springer, Dordrecht.

Rodriguez, H., Fraga, R., 1999. Phosphate solubilizing bacteria and their role in plant growth promotion. Biotechnol. Adv. 17, 319-339. 
44

P. Coll et al. / Applied Soil Ecology 50 (2011) 37-44

Sanchez-Moreno, S., Ferris, H., 2007. Suppressive service of the soil food web: effects of environmental management. Agric. Ecosyst. Environ. 119, 75-87.

Scullion, J., Neale, S., Philips, L., 2007. Earthworm casting and burrowing activity in conventional and organic grassarable rotations. Eur. J. Soil Biol. 43, S216-S221.

Smith, R., Bettiga, L., Cahn, M., Baumgartner, K., Jackson, L.E., Bensen, T., 2008. Vineyard floor management affects soil, plant nutrition, and grape yield and quality. Calif. Agric. 62, 184-190.

Steenwerth, K., Belina, K.M., 2008. Cover crops enhance soil organic matter, carbon dynamics and microbiological function in a vineyard agroecosystem. Appl. Soil Ecol. 40, 359-369.

Teixeira, R.F.M., Domingos, T., Costa, A., Oliveira, R., Farropas, L., Calouro, F., Barradas, A.M., Carneiro, J., 2011. Soil organic matter dynamics in Portuguese natural and sown rainfed grasslands. Ecol. Model. 222, 993-1001.

Van Bruggen, A.H.C., Semenov, A.M., 2000. In search of biological indicators for soil health and disease suppression. Appl. Soil Ecol. 15, 13-24.

Van Leeuwen, C., Friant, P., Chone, X., Tregoat, O., Koundouras, S., Dubourdieu, D., 2004. Influence of climate, soil, and cultivar on terroir. Am. J. Enol. Vitic. 55, 207-217.

Van Leeuwen, C., Seguin, G., 2006. The concept of terroir in viticulture. J. Wine Res. $17,1-10$.

Vestberg, M., Kukkonen, S., Saari, K., Tuovinen, T., Palojarvi, A., Pitkanen, T., Hurme, T., Vepsalainen, M., Niemi, M., 2009. Effects of cropping history and peat amendments on the quality of a silt soil cropped with strawberries. Appl. Soil Ecol. 42, 37-47.
Villate, L., Fievet, V., Hanse, B., Delemarre, F., Plantard, O., Esmenjaud, D., van Helden, M., 2008. Spatial distribution of the dagger nematode Xiphinema index and its associated Grapevine fanleaf virus in French vineyard. Phytopathology 98, 942-948.

Villenave, C., Ekschmitt, K., Nazaret, S., Bongers, T., 2004. Interactions between nematodes and microbial communities in a tropical soil following manipulation of the soil food web. Soil Biol. Biochem. 36, 2033-2043.

Villenave, C., Ba, A.O., Rabary, B., 2009. Diagnostic du fonctionnement biologique du sol par l'analyse de la nématofaune: semis direct versus labour sur les hautes terres près d'Antsirabé (Madagascar). E.G.S. vol. 16, pp. 369-378.

Villenave, C., Saj, S., Pablo, A.L., Sall, S., Djigal, D., Chotte, J.L., Bonzi, M., 2010. Influence of long-term organic and mineral fertilization on soil nematofauna when growing Sorghum bicolor in Burkina Faso. Biol. Fertil. Soils 46, 659-670.

Whitelaw-Weckert, M.A., Rahman, L., Hutton, R.J., Coombes, N., 2007. Permanent swards increase soil microbial counts in two Australian vineyards. Appl. Soil Ecol. 36, 224-232.

Wightwick, A.M., Salzman, S.A., Reichman, S.M., Allinson, G., Menzies, N.W., 2010. Inter-regional variability in environmental availability of fungicide derived copper in vineyard soils: an Australian case study. J. Agric. Food Chem. 58, 449-457.

Wu, J., Joergensen, R.G., Pommerening, B., Chaussod, R., Brookes, P.C., 1990. Measurement of soil microbial biomass $\mathrm{C}$ by fumigation extraction-an automated procedure. Soil Biol. Biochem. 22, 1167-1169.

Yeates, G.W., Bongers, T., Degoede, R.G.M., Freckman, D.W., Georgieva, S.S., 1993. Feeding-habits in soil nematode families and genera-an outline for soil ecologists. J. Nematol. 25, 315-331. 